\title{
Russian Urban Environment Research Review
}

\author{
Ksenia V. Reznikova* \\ Siberian Federal University \\ 79 Svobodny, Krasnoyarsk, 660041, Russia
}

Received 01.06.2018, received in revised form 03.09.2018, accepted 10.09.2018

Culturological and sociological research of Russian urban environment is a relatively young trend in the Russian humanities; before 1991, the urban environment research was only carried out within the framework of city planning surveys. In the 1990-s, sociological and culturological studies of urban environment began; in the 21st century, the number of such researches began to grow, with the greatest interest towards the actual environment conditions; only few researchers focus on the Soviet or pre-Revolutionary past. The main methods of Russian urban environment research are: overt observation, mapping (using GIS), interview and questionnaire survey. The researches focus not only and not rather on capital cities, but also on regional centres and small provincial towns. The important problems are the local, "non-façade" issues of the modern urban environment; those are not only the material components of the urban environment that are of the researchers' interest, but the intangible ones, such as emotions, perception by the residents, audial component of the city etc. In the contemporary researches of Russian urban environment, description and analysis of particular cases prevail over the theoretical generalizations, which proves the vibrant development of this field of study.

Keywords: urban environment, overt observation, mapping, zoning, microurbanism.

The reported study was funded by Russian Foundation for Basic Research, Government of Krasnoyarsk Territory, Krasnoyarsk Regional Fund of Science to the research project: "Transformation of urban environment of Krasnoyarsk in 1991-2017".

Research area: culturology.

Citation: Reznikova, K.R. (2018). Russian urban environment research review. J. Sib. Fed. Univ. Humanit. soc. sci., 11(9), 1467-1486. DOI: 10.17516/1997-1370-0316.

\section{Introduction}

Culturological and sociological research of Russian urban environment is a relatively young trend in the Russian humanities due to the long prohibition of sociology in our country and recent emergence of culturology as such. If we take a look at the urban

(C) Siberian Federal University. All rights reserved

* Corresponding author E-mail address: axu-ta@mail.ru

This work is licensed under a Creative Commons Attribution-NonCommercial 4.0 International License (CC BY-NC 4.0). 
environment researches carried out before 1991, we see that they were connected to city planning surveys and intended to ensure the proper insolation level (Bakharev, Orlova, 1990), environment maintenance (Chernysheva, 1984; Zhavoronkova, 1982), and noise restriction (Smoliar, 1981). During the Soviet period, the main actor of changes in the urban environment were the authorities: people's deputies (Zhavoronkova, 1982) or the socialistic system as such (Vinogradskiy, 1977), i.e. the urban environment was subordinate to the administrators above, and the citizens could hardly come up with any initiative.

In the 1990-s, sociological and culturological studies of the urban environment began; in the $21^{\text {st }}$ century, the number of such researches increased, causing the growth and subdivision of the topics studied by the researchers, methods adopted from various sciences, linguistics, geography, mathematics etc. widened and diversified. The researchers were interested not only in the capital and other densely populated cities, but also in the periphery provincial towns. From large and significant topics, the research passed to the previously unnoticed details and subtle issues. Below, we shall present an attempt to classify the contemporary Russian urban environment research by a number of parameters.

\section{Universal and particular topics in urban research}

Classifying contemporary urban research by the narrowness or wideness of the topic, it may be noticed that on one hand, there is a tendency of referring to the urban environment as a whole, without focusing on a certain city: in their works, E.Iu. Vitiuk and T.V. Bel'ko find matching representatives of the urban environment from all over the world (Vitiuk, 2012; Bel'ko, 2012); V. Murylev speaks of social and cultural problems "as a whole" (Murylev, 2008); E.S. Mel'nichuk contemplates on the influence made by metropolises as a whole on the youth in general, and then, from the experts', not the youngsters' point of view (Mel'nichuk, 2018); Iu.K. Osipov and O.V. Matekhina analyse various types of hardscape elements and their functions, peculiarities of their use, and only in the one but last paragraph of the article they name the city where the research was carried out (Novokuznetsk) (Osipov, Matekhina, 2015). But on the other hand, doubtlessly, the researchers turn to the specificity of the environment of a certain city, such as Moscow, Saint Petersburg, Rostov, Irkutsk, Kovdor, Nikel, Makhachkala, Vladivostok, Arkhangelsk, Tambov, Omsk, Tomsk, Kazan, Ufa etc. The listed cities witness the research relevance of regional centres and provincial towns besides the capital cities. 


\section{Temporal emphasis of the urban environment research}

Speaking of the temporal factor, the main academic works dedicated to urban environment studies written in the past 30 years were focused on the actual condition of the cities; in this regard, it is worthwhile looking at the article collection titled "Microurbanism. City in details", where almost every research finds a reference to the Soviet past and the way it lingers through the contemporariness in the abandoned buildings, and to the great Soviet heritage in the industrial Northern towns. Even though in the academic field there are single studies of ancient and Medieval cities (Borshchik, 2009; Lezina, 2005), pre-Revolutionary cities (Kamaeva, 2011) and cities of the Soviet period (Kotova, 2014; Bakanov, 2003); thus, E.S. Kotova traces the implementation of the "garden city" concept by E. Howard in different cities of the USSR, concentrating on Omsk and noticing that in the fifty years of the "garden city" existence, "from a property of certain Soviet city planning projects it turned into a metaphor, a title" (Kotova, 2014: 38).

\section{Methods and approaches to the contemporary urban environment research}

Contemporary urban environment studies may be classified by the methods applied in them. Majorly, those are methods traditional for sociology and culturology, such as questionnaire survey, interview, overt observation. For instance, for the studies of axiological orientation of the metropolis youth, E.S. Mel'nichuk used the expert survey method; but there are still questions to be asked to the author, such as, who were the experts, why it was decided to study the experts' ideas of the axiological orientation of the youth, not the opinions of the young people themselves (Mel'nichuk, 2018). However, it is still important to remark that the research carried out in the 2010-s apply the nonhumanities methods more and more often, such as using open source GIS common for geography mapping. However, mapping is not a revelation for culture sciences; it was actively used by the diffusionist school of F. Ratzel, L. Frobenius etc. The innovation is using GIS for the creation of "emotional maps" and urban environment zoning from the quality point of view.

The article collection titled "Microurbanism. City in details" is of special interest, for it presents an attempt to reinterpret the urban space from the point of view of a sincere, concerned citizen, not a distant theorist who considers the city as a dehumanizing, anonymizing space. And even though the authors of the collected articles tend to apply traditional, mostly qualitative methods, such as interview and overt observation, their 
general approach, microurbanism, is non-traditional. Its main peculiarities are the selection of non-standard research topics; journalistic style; absence of strict academic structure of the texts; aspiration not only to describe the peculiarities of the urban environment, but also to change them. Besides the term of "microurbanism" used in the book title, the main terms of the approach are: "onlooker" as an image of a citizen, a researcher who cares about everything going on in the city, who replaces the image of an "idler"; "shabbiness" as a peculiarity of city space, which stands for the visibility of older layers through and between the newer parts. O. Brednikova and O. Zaporozhets define the most relevant properties of microurbanism, remarking, though, that strict definition is not possible; it is rather descriptive, not analytic language; microoptics stand for close attention to details, little things in the urban life; anthropologism (Brednikova, Zaporozhets, 2014). It is important that the research priorities of the collected articles' writers are shifted from the attempts of objectivizing the urban environment, modelling the current processes and statistic accounting of opinions and feelings of certain citizens or travellers; it is not sociology, it is urbanism, with the "micro" prefix.

\section{The subject matter of the contemporary Russian urban environment research}

The range of topics addressed in the contemporary urban environment research is very wide; let us list only the most popular ones.

\section{City image research}

Having addressed a number of theoretic and methodological questions concerning the city image, using the system approach, I.N. Fel'dt finds out that the image of Arkhangelsk is directly related to the river, the Northern Dvina; for this reason, even though "Arkhangelsk has almost lost its historical architectural image completely, the river connects the city to its past" (Fel'dt, 2010: 121). The author also concludes that "the underlying quality of a city, to our mind, is in acting as a sort of an intermediary in the dialogue between the image of the city of the past and of the future, which takes place in the present" (Fel'dt, 2010: 121).

V.V. Cheremisin also studies the image of the city he refers to as the "city constructing consciousness": "city constructing consciousness means reflection of a real urban environment in the human mind, interaction between the city and its residents; it is a product of penetration of the urban problems into the social subjects' lives" 
(Cheremisin, 2008: 69). V.V. Cheremisin studies the city constructing consciousness (and the fact of its presence or absence) of Tambov citizens, through the associative experiment with the city name, as well as the sociological survey of the feelings evoked by the city etc.

To study the image of Tomsk, two researches were carried out by E.V. Sukhushina, A.Iu. Rykun and N.P. Pogodaev; one of them revealed that "true life of Tomsk is much deeper and much more diverse than its primitive image sometimes presented to the tourists" (Sukhushina et al., 2014: 86). The second research is concentrated on the image of Tomsk developed among the students (both insiders and outsiders); the authors developed a guide which included the maximum range of urban city components: education opportunities, transport infrastructure, future prospects, accommodation quality etc. and offered the respondents to evaluate each aspect.

Iu.R. Gorelova studies the perception of Omsk by the citizens, offering the respondents twenty oppositions to evaluate the city: big/small, dirty/clean, home/ strange etc.; on the basis of the research the author concluded that "among the problems, the respondents remarked the pollution of the urban space, chaoticity determined, inter alia, by the inconsistency of spatial references and monotonous environment, formed by the massiveness of nondescript panel high rises. Among the urban city lifestyle properties, the rapidness of processes and tension were mentioned" (Gorelova, 2017).

Studying the image of Irkutsk, Iu.V. Borisova found the correlation between the length of stay in the city and satisfaction with it; she also outlines the cognitive, affective and activity symbols typical of the respondents from the three groups: highly satisfied, medium satisfied and low satisfied (Borisova, 2017). Besides, Iu.V. Borisova analysed the emotions evoked by Irkutsk, its advantages and disadvantages revealed by the respondents of the three outlined groups. In each research, the author used such methods as a survey, expert interview and content analysis. Iu.V. Borisova concludes the work with the statement: "The development of harmonic urban environment will strengthen the positive image of Irkutsk. The key requirements are: the development of urban infrastructure, trade and industry, quality of public spaces $\langle\ldots$.. $>$. It is also necessary to develop the concept and practically implement the idea of "clean water" both in the city itself (in the water supply system) and in the open water bodies of the city. $<\ldots>$ The rich cultural and historical realities of Irkutsk should not be forgotten $<\ldots>$. It develops the identity of the citizens, attracts tourists and forms a sort of city branding which may serve as a basis for attracting investors in the future (Borisova, 2017). Besides the image of the city in the citizens' minds, the researchers are interested 
in the image of the city in mass media (Vsevolodova, 2013; Pushkareva, 2013), literature (Kovtun, 2012), and folklore songs (Emer, 2014).

\section{Urban environment quality research}

The urban environment quality is the subject of research by S.N. Bobylev, O.V. Kudriavtseva, S.V. Solov'eva, Ia.A. Leshchenko, V.N. Il'mukhin, M.V. Boykova etc. (Bobylev et al., 2014; Leshchenko, 2011; Il'mukhin, 2014; Boykova et al., 2011; Priadein, 2005; Loginov, 2012). Iu.V. Kataeva and A.V. Lapin developed a series of formulae with integrals to evaluate the urban environment quality on the basis of several criteria, including accommodation conditions, urban amenities, cultural and leisure facilities, institutional conditions, social security ( 9 criteria altogether) (Kataeva, Lapin, 2014: 32). With the developed formulae, the authors calculated the integral urban environment quality value for the cities of Volga Federal District in 2012. The greatest value was demonstrated by Kazan (0.611) and the lowest was that of Ufa (0.436) (Kataeva, Lapin, 2014: 38).

O.A. Poliushkevich and M.V. Popova analyse and classify the toponymics of Irkutsk to formulate its role in the identity construction, addressing several periods of renaming the urban objects, and conclude that "From the symbolic space planning point of view, Irkutsk has a great number of faults that make a negative impact on navigation around the city. From the point of view of rational and even distribution of symbolic and text indicators, at the present moment Irkutsk is a bright example of a disharmonic urban space" (Poliushkevich, Popova, 2017). The city toponymics also attract the attention of such researchers as T.L. Muzychuk, V.A. Sukhanov, A.I. Shcherbinin (Muzychuk, 2016a; Muzychuk, 2016b; Sukhanov, Shcherbinin, 2017).

The research of Kovdor town in Murmansk Oblast carried out by A. Zhelnina led to the revelation of two towns in one overlapping each other and visible through each other ("shabbiness"); A. Zhelnina also remarks that Kovdor is a "town for insiders" (any advertising hardly contains any certain addresses but local landmarks), a town of strong family bonds which has hardly any public spaces, a town perceived as a symbol of great industrial past by the senior generation and as a hopeless province by the middle one (Zhelnina, 2014).

E.S. Mel'nichuk studies the specificity of influence on the metropolis youth defined by the researcher as a "super sophisticated system of social self-organization, i.e. an autopoetic system" (Mel'nichuk, 2018: 124). First of all, in the context of Russia the subject matter is the youth of Moscow. The research of E.S. Mel'nichuk is based 
on the expert survey of the axiological milestones, the needs and aspiration of the youth living in metropolises and urban-type settlements. The researcher obtained the following results: in a metropolis, "the values prevailing for the modern youth are 'money, power, career' (61.7\%). The second place is occupied by $<\ldots>-$ - 'comfort, entertainment, attractive lifestyle' (53.2\%). The value shared the least is 'faith and love' (19.2\%), 'good and justice' (8.5\%)" (Mel'nichuk, 2018: 80-81).

\section{Urban zoning research}

E.A. Varshaver, A.L. Rocheva and N.S. Ivanova are developing a social district map as a way of urban environment research; they also remark that a social map of a district is "a tool and a separate research result that complements the urban anthropology arsenal; at the same time, $<\ldots>$ it is a convenient way of field data organization, for it can compactly describe the interview results (with the opportunity to analyse the text as well) and to visualize some social relations aspects relevant for analysis $<\ldots .>$; it is also a convenient method of presenting the spatial-social unit research results in a legible form with the opportunity of creating complicated and interactive multimedia interfaces $\langle\ldots>$, a basis for the change so desperately required within the framework of the "left" theoretical agenda of urban anthropology" (Varshaver et al., 2016: 47).

S.G. Pavliuk works on vernacular zoning, addressing the role of local toponymy which serves for the self-organization of the society; the researcher lists the classification criteria for local toponyms and their functions (Pavliuk, 2017). S.G. Pavliuk explains the importance of the problem with the fact that "a local toponym is one of the indicators of the space perception, of forming the spatial self-organization of the society and its sense of place. The process of naming the territory for an individual and (what is more relevant for a geographer) for the society transforms an abstract homogenous space into a certain place full of mental and social meaning. Moreover, local toponymy is the simplest indicator for the identification and analysis of the sense of place and space self-organization" (Pavliuk, 2017: 41).

O.D. Ivlieva and A.D. Iashunsky try the social media data analysis for the urban environment, and, particularly, urbanization research; the authors rely on the fact that statistic data do not reflect the real situation since they are connected to official residence registration; only social media data may be used to study the users' actual self-identification issues (Ivlieva, Iashunskiy, 2016). O.D. Ivlieva and A.D. Iashunsky remark a significant urbanization of VK social network users, and also that "in all the studied agglomerations except for Voronezh and Omsk, the number of registered VK 
users in the central city exceeds the actual population of the city. In the neighbouring municipal entities, the share of users is relatively small. <..> Hypothetically hypertrophied role of the centre proves the strong bonds between the periphery and the centre, and a great role of pendulum migration. $<_{\text {... }}>$ With the development of infrastructure and cohesion within the agglomeration, the territories adjacent to the core city get functionally and semantically assimilated with it, and in the consciousness of people get identified with it as well" (Ivlieva, Iashunskiy, 2016: 34).

Based on the example of Nikel town of Murmansk Oblast, T.V. Zhigal'tsova makes up "emotional maps" of the city for different age groups of the population; for this purpose, the respondents were asked to name the places that evoke positive or negative emotions in them, the ones they find frightening or mysterious etc.; Zhigal'tsova also offered her respondents to answer whether Nikel town was beautiful, safe, clean, unique, multicultural, or friendly (Zhigal'tsova, 2017). The research showed that for women Nikel is first of all a unique town (65\% of respondents) and for men, it is safe $(60 \%)$; both categories of respondents call Nikel a clean town least of all $(10 \%$ of women and $5 \%$ of men).

\section{Separate urban spaces research}

A.S. Gorlenko classifies modern sculpture parks of Saint Petersburg based on the following parameters: types of park location within the urban structure (landscape and urbanized parks); the principles of exposition and connection to the surrounding environment (ensemble-projected, exhibition) (Gorlenko, 2013). O. Tkach studies the "wedding landscape" of Saint Petersburg with the interview and overt observation methods, identifying the principles the couples use for choosing photoshoot spots, their behaviour during the walks, the reaction of onlookers etc. (Tkach, 2014).

V.B. Makhaev analyses the Mordovian University facilities from the points of view of city planning and architecture (Makhaev, 2008). Remarkably, modern urban environment researches do not concentrate only on the façade side of the cities, paying great attention to the other side of it, such as markets, yards, abandoned buildings. The abandoned objects are the subject matter of the research by R. Abramov and E. Shevelev, engaged in the classification of abandoned buildings, studies of various interaction practices used by the citizens etc. (Abramov, 2014; Shevelev, 2014). Based on the hardscape objects of the Khrushchev-era apartment block yards, I.V. Gibelev studies the non-functional localities found in the urban environment, remarking that "the hardscape objects act as substitutes for the deity statues" (Gibelev, 2014: 60); 
that these objects foresee nothing but indifferent perception of the potential viewers. O. Pachenkov and L. Voronkova compare two flea markets: Udelny market in Saint Petersburg and Mauerpark in Berlin as the urban walls that erase the borderlines between the private and the public (exhibiting one's personal belongings) (Pachenkova, 2014).

\section{Urban transport research}

The functioning of urban public transport is one of the relevant topics for the urbanist researchers: D.E. Briazgina, A. Ivanova, A.Iu. Ryzhkov etc. (Briazgina, 2017; Ivanova, 2014; Ryzhkov, 2016). A.Iu. Ryzhkov compares the peculiarities of minibuses as a means of public transport in Makhachkala and Bishkek, using geoinformation software to monitor the territory coverage by this means of transport, frequency of loops etc. (Ryzhkov, 2016). A.Iu. Ryzhkov finds out that in both cities the minibuses constitute the major part of public transport and cover around two-thirds of the city territory, but the quality of transport service does not completely satisfy the locals, but the municipal authorities do not attempt to improve the situation.

With the overt observation method, A. Ivanova studies the passenger behaviour in public transport of Rostov, using the "choreography" metaphor for the interpretation of her observations; A. Ivanova is mostly interested in the behaviour of passengers with large bags, since it is more involuntary in comparison to that of passengers without luggage (Ivanova, 2014).

\section{Research of the visual component of the urban environment}

S.M. Mikhailov, A.S. Mikhailova, N.M. Nadyrshin find six periods in the urban design history on the basis of the designer solutions of both Soviet, Russian cities and some foreign ones (Mikhailov et al., 2014). E.Iu. Vitiuk considers various capacities of painting, graphics (graffiti), advertising, illumination, installations for bringing more artistic value into the urban environment; at that, the author operates examples of both Russian and foreign cities (Vitiuk, 2012). A similar work is carried out by T.V. Bel'ko, who builds an evolution of the designer solutions of the urban environment: supergraphics - land art - public art - virtual reality (Bel'ko, 2012). Iu.K. Osipov and O.V. Matekhina study the peculiarities and functions of various hardscape objects, such as sculptures, water bodies etc. (Osipov, 2015).

The articles by N.A. Kalinenko and A.T. Sagnaeva, V.M. Novikova and S.V. Povysheva are dedicated to the problem of "videoecology", the field of study that 
"considers the visible environment as an ecological factor" (Kalinenko, Sagnaeva, 2009; Novikova, Povysheva, 2013: 199). Analysing the modern urban environment, V.M. Novikova and S.V. Povysheva conclude that it makes an aggressive influence on the person; "in an aggressive and homogenous environment the fundamental eyesight mechanism cannot work properly, the saccade automatism may be broken" (Novikova, Povysheva, 2013: 200). V.M. Novikova and S.V. Povysheva come up with the solution they refer to as "architectural bionics", "the architectural forms designed on a bionic basis, adapted to the natural environment, and, consequently, visually comfortable" (Novikova, 2013: 201). Based on the statement that "visual environment of a modern city makes a significant influence on the health and activity of people, being just the same environmental factor as light, temperature etc." (Kalinenko, Sagnaeva, 2009: 317 ); on the basis of questionnaire survey of 680 respondents, they study the perception of visual environment of Omsk and conclude that it "causes mostly controversial attitude with an inclination to the "positive"" (Klimenko, Sagnaeva, 2009: 326).

S.V. Malykh researches the influence made by outdoor advertising on the local identity of Irkutsk citizens, and notices different attitudes and different perceptions of such advertising by the locals, to the point that "the same advertising codes and messages may create positive images and symbols bringing harmony into the urban environment, therefore, changing and enhancing the territorial identity of the citizens; others, on the opposite, emphasize the social disorganization and dissociation, transmitting aggression and social anomy" (Malykh, 2017).

V.V. Baranova and K.S. Fedorova research the languages of migrants in the receiving language landscape of Saint Petersburg and analyse how much the obtained data illustrate the place occupied by the migrants in the city: "In the urban space, the visual presence, just like the absence of languages used in the everyday communication by the major part of the modern Petersburg population is an important evidence of the structure of the public urban space, of what is considered to be appropriate or inacceptable, and what restrictions are applied to written communication by the general social ideas of the language and attitude to language diversity" (Baranova, Fedorova, 2017: 103). The authors define linguistic landscape as an "aggregate visual existence of the language (and diverse languages) in a certain space. It includes route indicators, billboards and posters, signs, advertisements, graffiti, plates with the names of streets, districts, settlements etc., which present various information expressed through language in this or that graphics and visual forms" (Baranova, Fedorova, 2017: 104). V.V. Baranova and K.S. Fedorova find out that despite the great number of migrants in Saint Petersburg, 
the representation level of minority languages in the public sphere is extremely low, which means that "linguistic landscape analysis $\langle\ldots>$ is a means of revealing the under-representation of certain social and/or ethnic groups. The monolingual façade of a Russian metropolis keeps concealing the everyday linguistic and cultural diversity which, just like any other mysterious and discreet thing, seems to be frightening and confusing for the local citizens" (Baranova, Fedorova, 2017: 116). The presence of other ethnic groups besides the titular ones is also studied by L.N. Khakhovskaia based on the city of Magadan (Khakhovskaia, 2014) and N.I. Azisova based on Mordovian towns (Azisova, 2011).

Studying the public art objects of Vladivostok, E.S. Zadvornaia and L.G. Gorokhovskaia reveal that the majority of them (29\%) is connected with the image of a tiger; tigers are often found in different districts of the city, with the $62 \%$ of them being sculptures, and 24\% of them being graffiti (Zadvornaia, Gorokhovskaia, 2018). Interestingly, the initiative of installing tiger sculptures or pictures is predominantly directed upwards: $50 \%$ of them are gifts to the city (e.g., from WWF), $41 \%$ are created by people and only $9 \%$ are purchased by the municipal budget. With the deep interviews with the citizens, E.S. Zadvornaia and L.G. Gorokhovskaia found the main characteristics the people assign to the tiger: the "markedness" of the territory, the territory "guarded" by the tiger, fear of the tiger.

\section{Urban soundscape research}

Kh.R. Garaeva, A.N. Skvortsov, A.P. Savel'ev, S.V. P'ianzov address the acoustic component of the urban environment in its ecological aspect (Garaeva, 2010; Skvortsov et al., 2016). Kh.R. Garaeva is interested in the level of noise and its influence on the health of the people; the author considers the noise mostly in the negative aspect, as "noise pollution", the source of "noise disease", as a physically measurable indicator of the urban environment condition.

The acoustic component, the sound environment or the soundscape form the topic for the field study by M.A. Chubukova carried out in Arbat District of Moscow in 2013 (Chubukova, 2015). The author had been recording all sounds in the district within three days (18 hours) and then classified them by a number of properties, such as domination level; character; origin; dynamics; location; "friendliness" (Chubukova, 2015: 71). In the course of her research, M.A. Chubukova developed the "sound portraits of the streets" of Arbat District. E. Bunich studies the role of walkman in the city walk practices, remarking that music in the earphones changes both the audial and visual 
perception of the city; at the same time, E. Bunich speaks of "manipulating" the city perception with a walkman, such as the manipulation with rhythm, interactions etc. (Bunich, 2014). A. Voz'ianov also develops the soundscape topic, focusing mostly on the yard life, like the intimacy of sounds in the yard in comparison with the metropolis roar outside, the absence of silence, excuses the residents make for the sounds they produce etc. (Voz'ianov, 2014).

\section{Conclusion}

The analysis of Russian urban environment research draws a number of conclusions. Firstly, the culturological and sociological works in this sphere appeared not so long ago, in the 1990-s, while previously the urban environment peculiarities had been studied only by the construction engineers.

Secondly, today there is an interest for the actual condition of the urban environment; only single researches are based on the Soviet or pre-Revolutionary past.

Thirdly, the main methods of Russian urban environment researchare: overt observation, mapping (with GIS), interview and questionnaire survey; associative experiment, content analysis and other methods are rarely used. The non-humanities methods are attracted and tried for the urban environment studies (such as GIS, mathematic integrals).

Fourthly, the research interest is concentrated not only on the capital cities, but also on regional centres and on small provincial towns regardless of the geographic latitude and altitude; the list is wide, including Moscow, Saint Petersburg, Rostov, Irkutsk, Kovdor, Nikel, Makhachkala, Vladivostok, Arkhangelsk, Tambov, Omsk, Tomsk, Kazan, Ufa etc.

Fifthly, the most relevant are the local, even the "non-façade" problems of the urban environment, such as abandoned buildings, public transport passenger behaviour, yards, markets etc.

Sixthly, those are not purely material components of the urban environment (planning, architecture and sculpture) that attract the interest; those are also less tangible and harder to grasp components, such as emotions, perception of the residence place by the locals, audial component of the city life etc.

Seventhly, the peculiarities of the Russian urban environment research discourse can be formulated as follows: besides the analytical component, the descriptive one is widely represented. It creates the impression of prevalence of description and particular case analysis over the theoretical generalizations. On one hand, such descriptiveness helps grasping the actual condition of the environment with linguistic means of 
expression as accurate as possible; on the other hand, the rare theoretical conclusions witness the impossibility of covering and generalizing the processes going on in the environment. It means the tumultuous development of the present field of study, which has neither been brought into order nor reached stagnation.

\section{References}

Abramov, R. (2014). "Zabytye v proshlom": osvoenie zabroshennykh prostranstv i fenomen novogo gorodskogo turizma ["Forgotten in the past": the development of abandoned spaces and the phenomenon of new urban tourism], In Mikrourbanizm. Gorod v detaliakh [Microurbanism. City in details], 231-255.

Azisova, N.N. (2011). Mesto i rol' tatarskoy sem'i v etnokul'turnom prostranstve regiona [The place and role of a Tatar family in the ethno-cultural space of the region], In Vestnik Mordovskogo universiteta [Mordovian University Newsletter], 3, 206-213.

Bakanov, S.A. (2003). Malyy sovetskiy gorod 1960-80-kh gg. v zerkale otechestvennoy urbanistiki [Small Soviet city of the 1960-80s. in the mirror of domestic urbanistics], In Novyy istoricheskiy vestnik [New historical newsletter], 9. Available at: https:/cyberleninka.ru/article/v/malyy-sovetskiy-gorod-1960-80-h-gg-vzerkale-otechestvennoy-urbanistiki

Bakharev, D.V., Orlova, L.N. (1990). Iarkost' gorodskoy sredy [Brightness of the urban environment], In Svetotekhnika [Light Engineering], 1, 9-11.

Baranova, V.V., Fedorova, K.S. (2017). (Ne)vidimost' i (vne)nakhodimost': trudovye migranty i iazykovoy landshaft Sankt-Peterburga [(Not) visibility and (beyond) finding: labour migrants and the language landscape of St. Petersburg], In Gorodskie issledovaniia i praktiki [Urban research and practice], 1(2), 103-121.

Bel'ko, T.V. (2012). Evoliutsiia vizual'nykh kommunikatsiy gorodskoy sredy [Evolution of visual communications of the urban environment], In Izvestiia Samarskogo nauchnogo tsentra Rossiyskoy akademii nauk [News of Samara Scientific Centre, Russian Academy of Sciences], 14, 2(4), 1053-1057.

Bobylev, S.N., Kudriavtseva, O.V., Solov'eva, S.V. (2014). Indikatory ustoychivogo razvitiia gorodov [Sustainable urban development indicators], In Ekonomika regiona [The Regional Economy], 3, 101-110.

Borisova, Iu.V. (2017). Obraz goroda kak strategiia razvitiia (na primere Irkutska) [The image of the city as a development strategy (based on Irkutsk)], In Urbanistika [Urbanistics], 3, 81-92. Available at: http://nbpublish.com/library_read_article. php?id=24017 
Borshchik, N.D. (2009). Kursk i kuriane v XVII v. [Kursk and the Kursk citizens in the $17^{\text {th }}$ century], In Novyy istoricheskiy vestnik [New Historical Newsletter], 19, $14-20$.

Boykova, M.V., Il'ina, I.N., Salazkin, M.G. (2011). Budushchee gorodov: goroda kak agenty globalizatsii i innovatsiy [The future of cities: Cities as agents of globalization and innovation], In Forsayt [Foresight], 5(4), 32-48.

Brednikova, O., Zaporozhets, O. (2014). Mikrourbanizm. Lovushka dlia goroda [Microurbanism. Trap for the city], In Mikrourbanizm. Gorod $v$ detaliakh [Microurbanism. City in details], 13-42.

Briazgina, D.E. (2017). "Kitayskie” rynki i gorodskie mobil'nosti: sistema obshchestvennogo transporta $\mathrm{V}$ povsednevnosti goroda (na primere Irkutska) ["Chinese" markets and urban mobility: Public transport system in the daily city life (based on Irkutsk)], In Sibirskie istoricheskie issledovaniia [Siberian historical research], 1, 138-148.

Bunich, E. (2014). Po gorodu s pleyerom [Through the city with a walkman], In Mikrourbanizm. Gorod v detaliakh [Microurbanism. City in details], 94-110.

Cheremisin, V.V. (2008). Gradostroitel'noe soznanie i povedenie zhiteley goroda Tambova [City-planning consciousness and behaviour of Tambov citizen], In Vestnik Tambovskogo gosudarstvennogo universiteta [Tambov State University Newsletter], 9(65), 69-72.

Chernysheva, L.B. (1984). Kharakter vozdeystviia sistem gorodskogo rasseleniia iuga Dal'nego Vostoka na okruzhaiushchuiu sredu [The impact of urban settlement systems in the South of the Far East on the environment], In Rasselenie na Dal'nem Vostoke [Settlement in the Far East], 108-112.

Chubukova, M.A. (2015). Osobennosti zvukovoy sredy Arbatskogo rayona g. Moskvy [Peculiarities of the sound environment of Arbat District of Moscow], In Gorodskie issledovaniia i praktiki [Urban Research and Practices], Pilot Release, 67-78.

Emer, Iu.A. (2014). Obraz goroda v pesennom fol'klore [The image of the city in song folklore]. In Vestnik Tomskogo gosudarstvennogo universiteta. Filologiia [Tomsk State University Newsletter. Philology], 6 (23), 77-86.

Fel'dt, I.N. (2010). “Obraz goroda” kak fenomen mezhdistsiplinarnykh issledovaniy (na primere g. Arkhangel'ska) ["Image of the city" as a phenomenon of interdisciplinary research (based on Arkhangelsk)], In Vestnik Severnogo (Arkticheskogo) federal'nogo universiteta. Seriia: Gumanitarnye i sotsial'nye nauki [Northern (Arctic) Federal University Newsletter. Series: Humanities and Social Sciences], 5, 116-122. 
Garaeva, Kh.R. (2010). Akusticheskiy diskomfort v gorodskoy srede (na primere gorodov Baku i Astrakhan') [Acoustic discomfort in the urban environment (based on the cities of Baku and Astrakhan)], In Vestnik Astrakhanskogo gosudarstvennogo tekhnicheskogo universiteta [Astrakhan State Technical University Newsletter], 1(49), 88-95.

Gibelev, I.V. (2014). Nefunktsional'nye lokal'nosti gorodskoy sredy [Non-functional localities in the urban environment], In Znanie. Ponimanie. Umenie [Knowledge. Understanding. Ability], 4, 56-63.

Goloukhova, D.V. (2017). Metodologiia issledovaniia sotsial'no-territorial'noy struktury rossiyskogo goroda (na primere Moskvy) [The methodology of the study of the socio-territorial structure of a Russian city (based on Moscow)]. Moscow, $194 \mathrm{p}$.

Gorelova, Iu.R. (2017). Gorodskaia sreda v vospriiatii zhiteley krupnogo provintsial'nogo goroda (na materialakh g. Omska) [Urban environment in the perception of a large provincial city residents (based on Omsk)], In Urbanistika [Urbanistics], 1, 51-60. Available at: http://nbpublish.com/library_read_article.php?id=21203

Gorlenko, A.S. (2013). Parki sovremennoy skul'ptury v gorodskoy srede SanktPeterburga kontsa XX - nachala XXI vekov [Parks of modern sculpture in the urban environment of St. Petersburg in the late $20^{\text {th }}$ - early $21^{\text {st }}$ centuries], In Izvestiia Rossiyskogo gosudarstvennogo pedagogicheskogo universiteta im. A.I. Gertsena [Herzen Russian State Pedagogical University Newsletter], 161, 103-109.

Il'mukhin, V.N. (2014). Gorodskaia sreda kak faktor determinatsii povedencheskikh praktik: varianty sotsiologicheskoy kontseptualizatsii [Urban environment as a determinant of behavioural practices: sociological conceptualization variants], In Vestnik Rossiyskogo universiteta druzhby narodov. Seriia: sotsiologiia [Newsletter of Russian University of Peoples’ Friendship. Series: Sociology], 3, 87-98.

Ivanova, A. (2014). Sumchatyye. Khoreografiia passazhirov gorodskogo transporta [The marsupials. Choreography of public transport passengers], In Mikrourbanizm. Gorod v detaliakh [Microurbanism. City in details], 70-93.

Ivlieva, O.D., Iashunskiy, A.D. (2016). Virtual'naia urbanizatsiia [Virtual urbanization], In Gorodskie issledovaniia i praktiki [Urban research and practice], 4(1), 26-36.

Kalinenko, N.A., Sagnaeva, A.T. (2009). Vospriiatie vizual'noy sredy zhiteliami krupnogo goroda kak ekologicheskiy faktor (na primere g. Omska) [Perception of the visual environment by major city residents as an environmental factor (based on Omsk)], In Vestnik Cheliabinskogo gosudarstvennogo pedagogicheskogo universiteta [Chelyabinsk State Pedagogical University Newsletter], 11, 317-327. 
Kamaeva, E.V. (2011). Upravy uezdnykh gorodov Saratovskoy gubernii: dolzhnostnye litsa i effektivnost' raboty (1870-e-1914 gg.) [County town administrations in Saratov Province: officials and work efficiency (1870s-1914)], In Novyy istoricheskiy vestnik [New Historical Newsletter], 6-13.

Kataeva, Iu.V., Lapin, A.V. (2014). Formirovanie metodicheskogo podkhoda k integral'noy otsenke kachestva gorodskoy sredy [Forming a methodical approach to the integral assessment of urban environment quality], In Vestnik Permskogo universiteta. Seriia: Ekonomika [Perm University Newsletter. Series: Economics], 2(21), 31-39.

Khakhovskaia, L.N. (2014). Aborigeny v gorode: etnokul'turnyy oblik zhiteley Magadana [Aborigines in the city: ethnocultural image of Magadan citizens], In: Sibirskie istoricheskie issledovaniia [Siberian historical research], 2, 39-59.

Kotova, E.S. (2014). Gorod-sad: al'ternativnaia kontseptsiia formirovaniia gorodskoy sredy [Garden City: an alternative concept for urban environment development], In: Labirint [Labyrinth], 3, 32-39.

Kovtun, N.V. (2012). Obraz gorodskoy tsivilizatsii v pozdnikh rasskazakh V.M. Shukshina: mimeticheskiy i semanticheskiy aspekty [The image of urban civilization in the later stories of V.M. Shukshin: mimetic and semantic aspects], In Vestnik Tomskogo gosudarstvennogo universiteta. Filologiia [Tomsk State University Newsletter. Philology], 1(17), 74-93.

Leshchenko, Ia.A. (2011). Sotsial'no-ekologicheskie osnovy sistemnogo issledovaniia kachestva zhizni naseleniia goroda [Socio-ecological foundations for a systematic study of the quality of the urban population's life], In Ekologiia cheloveka [Human Ecology], 10, 42-47.

Lezina, E.P. (2005). Razvitie sistemy upravleniia v XVIII veke (formirovanie gorodskogo samoupravleniia) [Management system development in the $18^{\text {th }}$ century (urban self-government development)], In Vestnik Mordovskogo universiteta [Mordovian University Newsletter], 15(1-2), 57-62.

Loginov, V.G. (2012). Goroda kak sotsial'no-ekonomicheskaia osnova razvitiia rossiyskogo severa [Cities as a socio-economic basis for the development of the Russian North], In Ekonomika regiona [Regional economy], 3, 98-107.

Makhaev, V.B. (2008). Arkhitekturnyy kompleks Mordovskogo universiteta: proshloe, nastoiashchee i budushchee [Architectural complex of Mordovian University: past, present and future], In Vestnik Mordovskogo universiteta [Mordovian University Newsletter], 4, 4-10. 
Malykh, S.V. (2017). Rol' naruzhnoy reklamy v formirovanii obraza goroda [The role of outdoor advertising in shaping the image of the city], In Urbanistika [Urbanistics], 4, 40-47. Available at: http://nbpublish.com/library_read_article.php?id=24680

Mel'nichuk, E.S. (2018). Adaptatsiia molodezhi k sotsial'nym izmeneniiam v megapolise [Adaptation of young people to social changes in a megalopolis]. Moscow, $163 \mathrm{p}$.

Mikhailov, S.M., Mikhailova A.S., Nadyrshin N.M. (2014). Dizayn goroda: osnovnyye etapy istoricheskogo razvitiia [City design: the main stages of historical development], In Vestnik Orenburgskogo gosudarstvennogo universiteta [Orenburg State University Newsletter], 5(166), 4-9.

Murylev, V. (2008). Sotsial'no-kul'turnyye kharakteristiki gorodskoy sredy [Sociocultural characteristics of urban environment], In Analitika kul'turologii [Analytics of Culturology], 2(11). Available at: http://analiculturolog.ru/journal/archive/item/499article_32-3.html

Muzychuk, T.L. (2016). Informatsionnoe toponimicheskoe prostranstvo sibirskogo goroda: manipuliatsii soznaniem [Information toponymic space of a Siberian city: manipulation of consciousness], In Voprosy teorii i praktiki zhurnalistiki [Questions of theory and practice of journalism], 5(1), 143-153.

Muzychuk, T.L. (2016). SHKRABy iz MUDO: abbreviaturnyye slova v informatsionnom toponimicheskom prostranstve sibirskogo goroda [Abbreviation words in the information toponymic space of a Siberian city], In Voprosy teorii $i$ praktiki zhurnalistiki [Questions of theory and practice of journalism], 5(4), 665-672.

Novikova, V.M., Povysheva, S.V. (2013). Problemy videoekologii gorodskoy sredy [Problems of videoecology of the urban environment], In Izvestiia MGTU "MAMI" [Moscow State Technological University “MAMI” Newsletter], 4, 1(15), 199-202.

Osipov, Iu.K., Matekhina, O.V. (2015). Malyye arkhitekturnyye formy v prostranstve gorodskoy sredy [Hardscape objects in the urban environment space], In Vestnik Sibirskogo gosudarstvennogo industrial'nogo universiteta [Siberian State Industrial University Newsletter], 2(12), 61-63.

Pachenkov, O., Voronkova, L. (2014). Bloshinyy rynok kak "gorodskaia stsena" [Flea market as a "city scene"], In Mikrourbanizm. Gorod v detaliakh [Microurbanism. City in details], 132-169.

Pavliuk, S.G. (2017). Gorodskaia lokal'naia toponimiia kak indikator prostranstvennoy samoorganizatsii obshchestva [Urban local toponymy as an indicator of the spatial self-organization of society], In Gorodskie issledovaniia i praktiki [Urban research and practice], 2(2), 33-42. 
Poliushkevich, O.A., Popova, M.V. (2017). Simvolicheskoe konstruirovanie territorial'noy identichnosti (na primere toponimiki Irkutska) [Symbolic construction of territorial identity (based on Irkutsk toponymy)], In Urbanistika [Urbanistics], 3, 117-134. Available at: http://nbpublish.com/library_read_article.php?id=23665

Priadein, A.A. (2005). Strategiia razvitiia konkurentosposobnosti krupneyshego goroda [Major city competitiveness development strategy], In Ekonomika regiona [Regional economy], 4, 170-178.

Pushkareva, I.A. (2013). O semantiko-stilisticheskom voploshchenii obraza goroda v gazetnom tekste kraevedcheskogo kharaktera (tema «Dostoyevsky v Kuznetske» v gorodskoy gazete «Kuznetskiy rabochiy») [On the semantic-stylistic incarnation of the city image in the newspaper text of local lore ("Dostoevsky in Kuznetsk" theme in the city newspaper "the Kuznetsky Rabochiy")], In Vestnik Tomskogo gosudarstvennogo universiteta. Filologiia [Tomsk State University Newsletter. Philology], 3(23), 24-33.

Ryzhkov, A.Iu. (2016). Mikroavtobusy i transportnaia politika. Primery Bishkeka i Makhachkaly [Minibuses and transport policy. Based on Bishkek and Makhachkala], In Gorodskie issledovaniia i praktiki [Urban studies and practice], 1(1), 55-69.

Shevelev, E. (2014). Gorod (bez) cheloveka: praktiki osvoeniia pustykh i zabroshennykh prostranstv [City (without) people: the practice of developing empty and abandoned spaces], In Mikrourbanizm. Gorod v detaliakh [Microurbanism. City in details], 43-63.

Skvortsov, A.N., Savel'ev, A.P., P'ianzov, S.V. (2016). Otsenka akusticheskogo zagriazneniia selitebnoy territorii v g. Saranske [Assessment of acoustic pollution in a residential area in Saransk], In Vestnik Mordovskogo universiteta [Mordovian University Newsletter], 26(2), 218-227.

Smoliar, N.I. (1982). Issledovanie effektivnosti snizheniia shumovogo zagriazneniia gorodskoy sredy transportnymi potokami [Study of the effectiveness of reducing noise pollution of the urban environment by traffic flows]. Moscow.

Sukhanov, V.A, Shcherbinin, A.I. (2017). Zhizn' i smert' "Sibirskikh Afin": problema zhiznennogo tsikla metaforicheskogo toponima $\mathrm{V}$ razlichnykh diskursakh XX - nachala XXI vv. [Life and death of the "Siberian Athens": the problem of the life cycle of the metaphorical toponym in various discourses of the $20^{\text {th }}-$ early $21^{\text {st }}$ centuries], In Vestnik Tomskogo gosudarstvennogo universiteta. Filologiia [Tomsk State University Newsletter. Philology], 47, 149-170.

Sukhushina, E.V., Rykun, A.Iu., Pogodaev, N.P. (2014). Gorodskoe prostranstvo opyt issledovaniia [Urban space. Research experience], In Vestnik Tomskogo 
gosudarstvennogo universiteta. Filosofiia. Sotsiologiia. Politologiia [Tomsk State University Newsletter. Philosophy. Sociology. Political Science], 1(25), 84-98.

Tkach, O. (2014). Svad'ba v bol'shom gorode: na progulke [Wedding and the city: the walk], In: Mikrourbanizm. Gorod v detaliakh [Microurbanism. City in details], 170-209.

Varshaver, E.A., Rocheva, A.L., Ivanova, N.S. (2016). Sotsial'naia karta rayona kak instrument gorodskikh issledovaniy [Social map of the district as an instrument of urban research], In Gorodskie issledovaniia i praktiki [Urban studies and practice], 3(1), 31-52.

Vinogradskiy, V.G. (1977). Gorodskoy obraz zhizni pri sotsializme. Metodologicheskie problemy [Urban lifestyle under socialism. Methodological problems]. Saratov: Saratov State University. N.G. Chernyshevsky, 72 p.

Vitiuk, E.Iu. (2012). Gorodskaia sreda kak art-ob'ekt [Urban environment as an art object], In Vestnik Tomskogo gosudarstvennogo universiteta [Tomsk State University Newsletter], 364, 43-48.

Voz'ianov, A. (2014). “Korobka dlia zvukov?” O saundskeype gorodskogo dvora ["Soundbox"? On the soundscape of the city yards], In Mikrourbanizm. Gorod v detaliakh [Microurbanism. City in details], 111-131.

Vsevolodova, A.N. (2013). Mediaobraz gorodov Rossii v federal'nykh pechatnykh SMI [Media image of Russian cities in the federal print media], In Voprosy teorii $i$ praktiki zhurnalistiki [Theory and practice of journalism], 2, 152-158.

Zadvornaia, E.S., Gorokhovskaia L.G. (2018). Ob'ekty ulichnogo iskusstva v gorodskoy srede Vladivostoka: praktiki obrashcheniia s "tigrinymi" art-ob'ektami [The objects of street art in the urban environment of Vladivostok: the practice of dealing with "tiger" art objects], In Urbanistika [Urbanistics], 2, 35-49. Available at: http://nbpublish.com/library_read_article.php?id=25970

Zhavoronkova, N.G. (1982). Pravotvorcheskaia deiatel'nost' gorodskikh sovetov narodnykh deputatov $\mathrm{v}$ oblasti okhrany okruzhaiushchey sredy [Legislative activity of city councils of people's deputies in the field of environmental protection]. In Vestnik Moskovskogo universiteta. Seriia 11: Pravo [Moscow University Newsletter. Series 11: Law], 1, 65-70.

Zhelnina, A. (2014). “Zhelezo, sliuda, apatity i rossypi sudeb liudskikh...” Proshloe i nastoiashcheye v zapoliarnom industrial'nom gorode ["Iron, mica, apatites and placers of human destinies ..." Past and present in the polar industrial city]. In Mikrourbanizm. Gorod v detaliakh [Microurbanism. City in details], 256-280. 
Zhigal'tsova, T.V. (2017). Obrazno-emotsional'noe vospriiatie arkhitekturnoprostranstvennoy sredy malogo arkticheskogo goroda [An imaginative and emotional perception of the architectural and spatial environment of a small Arctic city]. In Urbanistika [Urbanistics], 4, 20-27. Available at: http://nbpublish.com/library_read_ article.php?id=24519

\title{
Обзор исследований городской среды России
}

\author{
К.В. Резникова \\ Сибирский федеральный университет \\ Россия, 660041, Красноярск, пр. Свободный, 79
}

\begin{abstract}
Культурологические и соииологические исследования городской среды России - относительно молодые направления в отечественной гуманитарной науке; до 1991 г. исследования городской среды проводились в рамках градостроительных изысканий. В 1990-е г2. появляется сочиологическое и культурологическое изучение городской среды, в XXI в. исследований такого рода становится все больше, при этом наблюдается интерес преимущественно к актуальному состоянию городской среды, лишь в отдельных исследованиях акиентируется внимание на советском или дореволюиионном прошлом. В качестве основных методов исследования городской среды России могут быть названы включенное наблюдение, картографирование (с помощью ГИС), интервьюирование и анкетирование. В иентре исследовательских интересов оказываются не только и не столько столичные города, но региональное иентры, а также провинииальные мелкие города. Важныли становятся локальные, даже «нефасадные» проблемы городской среды; при этом интерес представляют не только сугубо вещественные составляюшие городской среды, но и более неуловимые - эмочии, восприятие горожанами своего места проживания, аудиальная составляющая города и др. Также в современных исследованиях городской среды России ощущается превалирование описания и анализа частных случаев над теоретическими обобщениями, что свидетельствует о бурном развитии данного направления.
\end{abstract}

Ключевые слова: городская среда, включенное наблюдение, картографирование, районирование, микроурбанизм.

Исследование выполнено при финансовой поддержке Российского фонда фундаментальных исследований, Правительства Красноярского края, Красноярского краевого фонда науки в рамках научного проекта: «Трансформащия городской среды Красноярска в 1991-2017 г2.».

Научная специальность: 24.00.00 - культурология. 